convenience of Fisher's notation depends on the precise cytological basis of these facts. The most likely explanation consists in the existence of three very closely linked loci, but one cannot at present rule out the possibility of some such mechanism as that of a single gene with three side-chains each capable of variation. Even for this type of mechanism, Fisher's notation would give a more complete and convenient specification than that of Wiener. It should also be pointed out that Wiener's present nomenclature differs greatly from that originally put forward, and a claim of priority for it can scarcely be based on the fact that his original system was published before that of Fisher.

The compromise reached is an advance on previous American practice, and indirectly will do much to enable workers on the $R h$ factor in different parts of the world to understand one another's language. It is, however, to be regretted that Fisher's notation is relegated to parentheses; while its obvious advantages will ensure its use in research work, the first name on the label will tend to be perpetuated among clinical pathologists.

A. E. MourantT

${ }^{1}$ Castle, W. B., Wintrobe, M. W., and Snyder, L. H., Science, 107, 27 (1948).

'Flsher, R. A., personal communication cited by Race, R. R., Nature 153, 771 (1944)

\section{PROPOSED INSTITUTE OF RECORDED SOUND}

$\mathrm{T}$

HE Association of Special Libraries and Information Bureaux has taken the initiative, in response to a large number of requests, of calling together representatives and individuals known to be interested in the formation of a permanent means of collecting, and making available to students and others, documentary and artistic material in the form of recorded sound. A meeting was therefore held on March 3 to discuss the matter, and to ascertain what is practicable now and in the near future.

Mr. Frank Howes (president of the Royal Musical Association), as chairman, gave an outline of the proposals already put forward in general terms, and the usefulness of such a potential organisation, started perhaps on the lines of the British Film Institute, was detailed by representatives of such important bodies as the British Museum, the British Council, the British Broadcasting Corporation (which uses sound recording on an immense scale in many forms), the National Register of Archives, the Scientific Film Association, the English Song and Folk Dance Society, the International Folk Music Council, departments of the University of London interested in languages, the commercial and private recording companies, the professional societies, and other individuals.

Mr. A. P. H. Saul described how collections of recorded material have been built up elsewhere, both on the Continent, especially Vienna, over the past fifty years, in Berlin and in the United States; but facilities are totally lacking in Great Britain. As a consequence valuable historical material is being lost, or at the best dispersed in private collections, of which no information is readily available. The interpretations of musicians, the voices of statesmen and poets, the remoter languages, the interesting cases of defective speech, and strange music of other lands are probably all available somewhere, but are denied to serious students of history, anthropology and phonetics.
Since practice is often better than mere precept, the value of such records was demonstrated most effectively by Mr. H. L. Fletcher, who played montage records, with comments, made that morning, from material received from a number of sources. Thus were reproduced the voices of Lloyd George, Asquith, James Joyce, Woodrow Wilson, Vesta Tilly (all pre-1914), Japanese music, an original 1660 pipe organ, a man of eighty recalling the original tune of "Brigg Fair", and modern poets. Also the voices of Gladstone, and, of course, all sing irs since 1900 are known to be available.

Questions of the copyright in reproductions for practical use, storage, finance, interchange with other countries, research and relations with other interested bodies were generally discussed. The meeting constituted itself a provisional council, hav. ing approved the idea that such an institute should go forward, and appointed a committee to study details and make a report.

With Mr. F. Howes as chairman the following were appointed to this exploratory committee: Mr. P. May (A.S.L.I.B.), Mr. A. P. H. Saul, Dr. D. B. Fry (Phonetics Department, University College, London), Mrs. J. Lancaster-Jones (British Council), Mr. D. Shawe-Taylor, Mr. A. C. Cameron (Educational Department, Electric and Musical Industries, Ltd.), Mr. H. L. Fletcher (Association of Professional Recording Studios) and Dr. L. E. C. Hughes (British Sound Recording Association).

\section{FORTHCOMING EVENTS}

(Meeting marked with an asterisk * is open to the public)

\section{Tuesday, March 30}

MANCHESTER Geographical Societry (in the Geographical Hall, St. Mary's Parsonage, Manchester), at 6.30 p.m.-Mr. H. E. Faulkner : "The East India Company".

SOCIETY OF INSTRUMRNT TECHNOLOGY (at the Royal Society of Tropical Medicine and Hygiene, Manson House, 26 Portland Place, London, W.1), at 6.30 p.m.-Mr. S. S. Carlisle and Mr. B. O. Smith: "An Experimental Electrical Pressure Meter for Measurement of Furnace Roof Differential Pressures".

ROYAL PHOTOGRAPHIC SOCIETY, SCIENTIFT AND TECHNICAL GROUP (at 16 Prince's Gate, London, S.W.7), at 7 p.m.-Symposium on "Modern Techniques in Stereoscopy and their Applications".

\section{Wednesday, March 31}

Manchester Literary and Philosophical Soctety, Sociat PHILOSOPHY SECTION (in the Portico Library, 57 Mosley Street, sophy in Christian Civilization".

British Institution of RADIO ENGINEERS, MERSEyside SRCTION (at the Liverpool Engineering Society, 9 The Temple, 24 Dale Street, Liverpool), at 6.45 p.m.-Mr. J. B. Birks: "The Physical Applications of Micro-Waves"

\section{Thursday, April I}

Mineralogical Society (at the Geological Society of London, Burlington House, Piccadilly, London, W.1), at 5 p.m. - Scientiflc Papers.

InSTTTUTION OF ELECTRICAL ENGINEERS (at Savoy Place, Victoria Embankment, London, W.C.2), at 5.30 p.m-Mr. R. J. Halsey and Dr. J. H. Swaffield : "Analysis-Synthesis Telephony with Special Reference to the Vocoder"

INSTITUTION OF CIVIL ENGINRERS, NORTH-WESTERN AsSOCIATION (at the Engineers' Club, Albert Square, Manchester), at 6.30 p.m.Mr. F. D. C. Henry : "The Development of Motorway Projects".

ROXAL STATISTICAL SOCIETY, SHZFFIRLD GROUP OF THE INDUSTRIAL APPLICATIONS SECTION (in Room B1, Department of Mechanica Engineering, The University, St. George's Square, Sheffield, at Con p.m. - Mr. G. Komlosvi,"

Thursday, April 1-Saturday, April 3

SCIENOE Masters' Assoctation, Scotrish BRANCH (at the University, Glasgow).-First Annual General Meeting. 